\title{
Alat Permainan Edukasi (APE) Meningkatkan Perkembangan Motorik Halus pada Anak Usia 4-6 Tahun
}

\section{Educational Game Equipment Promotes Fine Motoric Development in Children 4-6 Years}

\author{
Mirna Lisa ${ }^{1}$, Ani Mustika ${ }^{2}$, Neneng Siti Lathifah ${ }^{3}$ \\ Jurusan Kebidanan, Universitas Malahayati Lampung, Indonesia
}

\section{ARTICLE INFO}

\section{Article history: \\ Received date \\ 13 Mar 2020 \\ Revised date \\ 17 Mar 2020 \\ Accepted date \\ 30 Apr 2020}

\section{Keywords:}

Children;

Fine motoric;

Games.

Kata kunci:

Anak;

Motorik halus:

Permainan.

\author{
ABSTRACT/ ABSTRAK
}

Games that are available today do not all contain elements of education that can help children's brain growth. Choosing educational toys that educate children today is indeed not easy. Based on a preliminary survey on January 10, 2019, conducted at Al-Kautsar Kindergarten out of 10 mothers, it was found that $6(60 \%)$ mothers who gave playing equipment were not based on educational play equipment for their children and $4(40 \%)$ mothers who gave toys to their children based on tools educational game to his child. Hypothesis there is the effect of giving APE to the development of fine motor children in 4-6 years. This type of quantitative research is quasi-experimental design with one group pretest and posttest design. The population of children in Al-Kautsar Kindergarten is 150 people, a sample of children aged 4-6 years in Al-Kautsar Kindergarten is 51 people. Sampling technique with accidental sampling. Dependent Research Variables Educational Game Tools and Independent Variables are Fine Motor Development. The time of this research is 4 months. The method used starts from pretest about fine motor skills of children and then carried out with interventions with 10 indicators and posttest. The results obtained are the effect of providing Educational Tools to children aged 4-6 years in Kindergarten AL-Kautsar with p-value 0,000 so it is smaller than the p-value of $\alpha(<0,005)$.

Permainan yang tersedia saat ini tidak semua mengandung unsur pendidikan yang dapat membantu pertumbuhan otak anak. Memilih alat permainan edukatif yang mencerdaskan anak saat ini memang tidak mudah. Berdasarkan survey pendahuluan tanggal 10 Januari 2019 yang dilakukan di TK Al-Kautsar dari 10 orang ibu didapatkan $6(60 \%)$ ibu yang memberikan alat permainan tidak berdasarkan alat permainan edukasi pada anaknya dan $4(40 \%)$ ibu yang memberikan mainan pada anaknya berdasarkan alat permainan edukatif kepada anaknya.Hipotesis ada pengaruh pemberian APE terhadap Perkembangan motorik halus anak 4-6 tahun. Jenis penelitian kuantitatif dengan rancangan quasi eksperimen desain one group pretest dan posttest design. Populasi anak di TK Al-Kautsar 150 orang, sampel anak yang berusia 4-6 tahun di TK Al-Kautsar sebanyak 51 orang. Tekhnik pengambilan sampel dengan Accidental Sampling. Variabel Penelitian dependen Alat Permainan Edukasi dan Variabel Independen adalah Perkembangan Motorik Halus. Waktu Penelitian ini selama 4 bulan. Metode yang di gunakan di mulai dari Pretest tentang motorik halus anak lalu dilakukan dengan intervensi dengan 10 indikator dan di lakukan posttest.Hasil yang didapat ada pengaruh pemberian Alat Permainan Edukatif pada anak usia 4-6 tahun di TK AL-Kautsar dengan p-value 0,000 sehingga lebih kecil dari nilai $\alpha(<0,005)$.

Corresponding Author:

Neneng Siti Lathifah

Jurusan Kebidanan, Universitas Malahayati Lampung, Indonesia

Email: nenengmalahayati@gmail.com

\section{PENDAHULUAN}

Sejalan dengan perkembangan teknologi dan informasi saat ini permainan juga ikut tumbuh dan berkembang khususnya melalui media-media elektronik seperti ponsel, game player, dan televisi. Permainan-permainan anak sewaktu masih kecil dulu kini sudah hampir tidak 
ada, khususnya untuk anak-anak yang tinggal di perkotaan, mereka tidak akan pernah mengenal permainan tradisional yang ada di pedesaan. Permainan yang tersedia saat ini tidak semua mengandung unsur pendidikan yang dapat membantu pertumbuhan otak anak. Ada beberapa bentuk dan jenis permainan yang mengandung unsur pendidikan yang dapat membantu proses tumbuh kembang anak dan ada yang berdampak negatif terhadap anak. Memilih alat permainan edukatif yang mencerdaskan anak saat ini memang tidak mudah.

Anak memiliki suatu ciri yang khas yaitu selalu tumbuh dan berkembang sejak kecil sampai berakhirnya masa remaja. Hal ini yang membedakan anak dengan dewasa. Pertumbuhan terjadi secara simultan dengan perkembangan. Berbeda dengan pertumbuhan, perkembangan merupakan hasil interaksi kematangan susunan saraf pusat dengan organ yang dipengaruhinya misalnya perkembangan sistem neuromuskuler, kemampuan bicara, emosi dan sosial (Kemenkes RI, 2015).

Tumbuh kembang anak yang pernah menggunakan alat permainan edukatif mempunyai perbedaan dalam pemberian stimulasi, anak yang pernah menggunakan alat permainan, anak mendapatkan stimulasi yang lebih, dibandingkan anak yang tidak menggunakan permainan edukatif (Karli, 2007).

Menurut Nursalam (2005) permainan yang dapat mengoptimalkan perkembangan anak sesuai usia dan tingkat perkembangannya serta berguna untukpengembangan aspek fisik, bahasa, kognitif dan sosial anak adalah APE. Sebelum memberikan permainan pada anak, orang tua seharuanya mengetahui maksud dan tujuan permainan yang akan diberikan, untuk mengetahui perkembangan anak lebih lanjut (Harlisa, 2010).

TK Al-Kautsar merupakan sekolah swasta yang mempunyai jumlah siswa 150 orang dengan rata rata umur 4-6 tahun. Letak yang strategis di Kota Bandar Lampung dan merupakan sekolah TK yang bernuansa islami dan fasilitas yang sangat memadai. Adanya alat permainan edukasi, hanya ditemukan masalah yang berkaitan dengan motorik halus anak belum berkembang sesuai harapan contohnya kurangnya kelenturan jari jemari anak, kecepatan jari jemari anak, ketepatan jari jemari anak.

Perkembangan intelektual manusia pada usia empat tahun sudah mencapai $50 \%$, usia 8 tahun $80 \%$, dan pada usia 18 tahun bisa mencapai $100 \%$. Berdasarkan penelitian tersebut maka masa usia dini adalah masa golden age yang harus dioptimalkan karena sebagian besar perkembangan otak anak didominasi pada masa tersebut yakni mencapai $80 \%$ sedangkan $20 \%$ selanjutnya akan berkembang setelah masa usia dini hingga umur 18 tahun (Bloom, 1976).

Banyak penelitian menunjukkan betapa masa dini usia, yaitu masa lima tahun ke bawah, merupakan golden ages (masa keemasan) bagi perkembangan kecerdasan anak. Salah satu hasil penelitian menyebutkan bahwa pada usia 4 tahun kapasitas kecerdasan anak telah mencapai $50 \%$ (Mutiah, 2015).

Ada beberapa bentuk dan jenis permainan yang mengandung unsur pendidikan yang dapat membantu proses tumbuh kembang anak dan ada yang berdampak negatif terhadap anak.

Ditemukan sejumlah besar orang tua masih memberikan alat permainan pada anak yang kurang sesuai dengan usia dan perkembangannya yaitu Berdasarkan survey pendahuluan tanggal 10 Januari 2019 yang dilakukan di TK Al-Kautsar dari 10 orang ibu didapatkan $6(60 \%)$ ibu yang memberikan alat permainan tidak berdasarkan alat permainan edukasi pada anaknya dan 4 (40\%) ibu yang memberikan mainan pada anaknya berdasarkan alat permainan edukatif kepada anaknya. Studi ini penting dilakukan karena perkembangan motorik halus melibatkan otot-otot kecil anak dan koordinasi antara mata dan tangan. Gangguan perkembangan motorik halus dapat menyebabkan beberapa masalah. Seorang anak mungkin kesulitan belajar, tidak bisa mandiri, hingga merasa tidak percaya diri karena tidak terampil menggunakan tangannya untuk melakukan tugastugas yang seharusnya bisa dilakukan anak seusianya. Karena keterampilan ini sangat penting untuk mendukung kehidupannya kelak. Koordinasi antara mata dengan tangan dapat dikembangkan melalui kegiatan bermain, membentuk memanipulasi dari tanah liat atau lilin, adonan, mewarnai, menempel, memalu, menggunting, merangkai benda dengan benang (meronce), memotong, menjiplak bentuk. Kemampuan daya lihat merupakan kegiatan kemampuan motorik halus lainnya melatih kemampuan anak melihat ke arah kiri dan kanan, atas bawah yang penting untuk persiapan membaca awal. Posisi anak balita disatu pihak berada pada masa rawan dan labil manakala anak kurang mendapatkan rangsangan positif dan menyeluruh. Kurangnya stimulasi permainan pada anak dapat menyebabkan penyimpangan tumbuh kembang anak. Bila perkembangan motorik halus ini terlambat, berbahaya bagi penyesuaian sosial dan pribadi anak yang baik sehingga mempengaruhi masa depannya. Serta kurangnya stimulasi atau kegiatan yang bersifat 
fisik khususnya motorik halus akan mengakibatkan anak memiliki gangguan konsentrasi pada saat anak telah duduk di sekolah dasar yang diakibatkan karena motorik halus anak belum matang

Tujuan penelitian diketahuinya pengaruh Alat Permainan Edukasi (APE) terhadap perkembangan motorik halus pada anak usia 4-6 tahun di TK Al-Kautsar Bandar Lampung. Kegunaan penelitian mampu menerapkan Alat Permainan Edukasi (APE) sesuai dengan usia anak sehingga perkembangan motorik halus anak lebih optimal hasilnya guna persiapan menuju tahap sekolah.

\section{METODE}

Jenis penelitian yang digunakan adalah kuantitatif dengan pendekatan Quasy eksperiment desain one group pre-test dan post-test. Variabel penelitian terdiri dari independen yaitu alat permainan pdukasi, variabel dependen yaitu perkembangan motorik halus pada anak TK AlKautsar Umur 4-6 tahun.Populasi anak di TK AlKautsar 150 orang dengan sampel anak yang berusia 4-6 tahun di TK Al-Kautsar sebanyak 51 anak dengan umur 4-6 tahun. Teknik pengambilan sampel dengan purposive sampling. Alat ukur menggunakan Kuesioner Pra Skrining Perkembangan (KPSP), kriteria penilaian pada aspek perkembangan motorik halus. Penelitian dilakukan sejak bulan 4-6 Juli 2019. Alat permainan edukasi yang digunakan seperti balokbalok, meronce, menggambar dan menggunting. Analisis yang digunakan adalah analisis univariat untuk menilai mean atau rata-rata, median dan standar deviasi perkembangan motorik halus sebelum dan sesudah di berikan alat permainan edukatif, Analisis bivariat dengan menggunakan uji t-test independent digunakan untuk membandingkan rata-rata dua set data (data sebelum dan sesudah) yang saling berpasangan. Dalam penelitian ini dua set data adalah alat permainan edukatif terhadap perkembangan motorik halus pada anaksebelum dan sesudah perlakuan pada taraf kepercayaan $95 \%(\alpha 0,05)$.

Penelitian ini telah melewati kaji etik dan memperoleh Keterangan Kelaikan Etik dengan Nomor 238/EC/KEP-UNMAL/I/2019 oleh Komisi Etik Penelitian Kesehatan Universitas Malahayati.

\section{HASIL}

Tabel 1. Rerata Perkembangan Motorik Halus sebelum dan sesudah Diberikan Alat Permainan Edukasi pada Anak Umur 4-6 tahun

\begin{tabular}{lcccc}
\hline \multicolumn{1}{c}{ Kelompok } & n & Mean & SD & $\begin{array}{c}\text { Min- } \\
\text { Max }\end{array}$ \\
\hline $\begin{array}{l}\text { Perkembangan } \\
\text { Motorik Halus }\end{array}$ & 51 & 21,8235 & 4,528602 & $10,00-$ \\
$\begin{array}{l}\text { sebelum } \\
\text { diberikan APE }\end{array}$ & & & 35,00 \\
\hline $\begin{array}{l}\text { Perkembangan } \\
\text { Motorik Halus }\end{array}$ & 51 & 25,1569 & 4,20177 & 39,00 \\
$\begin{array}{l}\text { sesudah } \\
\text { diberikan APE }\end{array}$ & & & \\
\hline
\end{tabular}

Dari tabel 1 dapat diketahui bahwa distribusi perkembangan motorik halus sebelum diberikan APE mempunyai rata rata 21,8235 dan rata rata setelah di berikan APE sebesar 25,1569.

Setelah dilakukan pengolahan data menggunakan uji $t$ dependent, dari perbedaan rerata perkembangan motorik halus pada anak 46 tahun di TK Al-Kautsar Bandar Lampung diperoleh hasil sebagai berikut:

Tabel 2. Pengaruh Alat Permainan Edukasi terhadap Perkembangan Motorik Halus pada Anak Umur 4-6 tahun

\begin{tabular}{llcrrr}
\hline \multicolumn{1}{c}{ Kelompok } & \multirow{2}{*}{ n } & Mean & p-value & \multicolumn{2}{c}{ CI } \\
\cline { 5 - 6 } & & & Lower & Upper \\
\hline $\begin{array}{l}\text { Perkembangan Motorik } \\
\begin{array}{l}\text { Preintervensi-Perkembangan } \\
\text { Motorik Halus Post Intervensi }\end{array}\end{array}$ & 51 & 3,33333 & 0,006 & 4.32160 & 2.34507 \\
\hline
\end{tabular}

Berdasarkan tabel 2 dari jumlah responden 51 orang diperoleh $p$-value 0,006 lebih kecil dari nilai alpha $(0,005)$ sehinggaada pengaruh Alat Permainan Edukasi terhadap Perkembangan Motorik Halus pada anak umur 4-6 tahun di TK Al-Kautsar Bandar Lampung.

\section{PEMBAHASAN}

Pada hasil penelitian didapatkan hasil sebelum dilakukan intervensi APE diketahui perkembangan motorik halus pada anak usia 4-6 tahun dalam kelompok Berkembang sesuai harapan dengan mean 21,8235, setelah dilakukan 
intervensi APE didapatkan hasil anak dalam kelompok Berkembang sesuai harapan dengan mean 25,1569, pada uji bivariat didapatkan nilai p-value sebesar 0,006 lebih kecil dari nilai alpha $(0,005)$. Sehingga ada pengaruh Alat Permainan Edukasi terhadap Perkembangan Motorik Halus pada anak umur 4-6 tahun di TK Al-Kautsar Bandar Lampung.

Anak memiliki ciri yang khas yaitu selalu tumbuh dan berkembang sejak konsepsi sampai berakhirnya masa remaja. Hal ini yang membedakan anak dengan dewasa. Anak bukan dewasa kecil. Anak menunjukkan ciri-ciri pertumbuhan dan perkembangan yang sesuai dengan usianya. Pertumbuhan adalah bertambahnya ukuran dan jumlah sel serta jaringan interselular, berarti bertambahnya ukuran fisik dan struktur tubuh sebagian atau keseluruhan, sehingga dapat diukur dengan satuan panjang dan berat. Perkembangan adalah bertambahnya struktur dan fungsi tubuh yang lebih kompleks dalam kemampuan gerak kasar, gerak halus, bicara dan bahasa serta sosialisasi dan kemandirian (Kemenkes RI, 2015). Faktor yang mempengaruhi tumbuh kembang ada faktor genetik dan faktor lingkungan (Sulistyawati, 2014).

Periode penting dalam tumbuh kembang anak adalah masa balita, karena pada masa balita pertumbuhan dasar akan mempengaruhi dan menentukan perkembangan anak selanjutnya. Dalam perkembangan anak terdapat masa kritis, dimana diperlukan rangsangan atau stimulasi yang berguna agar potensi berkembang. Perkembangan anak akan optimal bila interaksi sosial diusahakan sesuai kebutuhan anak sesuai tahap perkembangannya (Andriana, 2011).

Golden age dimulai dari anak baru lahir sampai dengan 6 tahun, karena masa ini sangat menentukan seperti apa mereka kelak jika dewasa baik dari segi fisik, mental maupun kecerdasan. Tentu saja ada banyak faktor yang akan sangat mempengaruhi mereka dalam perjalanan mereka menuju kedewasaan, tetapi apa yang mereka dapat dan apa yang diajarkan pada mereka pada usia dini akan tetap membekas dan bahkan memiliki pengaruh dominan dalam mereka menentukan setiap pilihan dan langkah hidup (Gunarti, 2014).

Penilaian Tumbuh Kembang anak dideteksi dengan menggunakan Kuesioner Pra Skrining Perkembangan (KPSP) yang disesuaikan dengan usia anak. Apabila dideteksi perkembangan anak hasilnya sesuai dengan usia perkembangan berarti anak berhasil menyesuaikan diri dengan tahap perkembangan secara normal, dan jika dideteksi diperoleh keterlambatan (meragukan) dan penyimpangan pada perkembangan anak, maka diberikan intervensi stimulasi alat permainan edukatif selama 2 minggu per 3-4 jam setiap hari (Sain, 2013).

"Pola perkembangan atau tingkat pencapaian anak usia lima sampai enam tahun yaitu; menggambar sesuai gagasannya, meniru bentuk, melakukan eksplorasi dengan berbagai media dan kegiatan, menggunakan alat tulis dengan benar, menggunting dengan sesuai pola, menempel gambar dengan tepat, dan mengekspresikan diri melalui gerakan menggambar secara detail." (Hasanah, 2016).

Motorik halus merupakan keterampilan fisik yang melibatkan otot-otot ujung jari serta koordinasi mata dan tangan. Bagian tubuh lain yang terlibat dalam kegiatan motorik halus adalah pergelangan tangan, lengan, sampai pangkal lengan atas dan bagian sendi di bahu. Motorik halus dapat dilatih dan dikembangkan melalui kegiatan dan stimulasi secara rutin, seperti bermain puzzle, menyusun balok, memasukan benda ke dalam lubang sesuai bentuknya dan sebagainya. Motorik halus merupakan keterampilan fisik yang melibatkan otot-otot ujung jari serta koordinasi mata dan tangan. Gerakan motorik halus mempunyai peranan yang penting dalam pengembangan seni. Motorik halus adalah gerakan yang hanya melibatkan bagian-bagian tubuh tertentu yang dilakukan oleh otot-otot kecil. Seperti, gerakan jaridan pergelangan tangan (Bakhtiar, 2015).

Salah satu kemampuan yang dikembangkan di TK adalah perkembangan motorik halus. Perkembangan motorik halus berkaitan dengan perkembangan kemampuan dalam menggunakan jari-jari tangan untuk melakukan berbagai kegiatan. Misalnya, kemampuan memindahkan benda dari tangan, mencoret-coret, menyusun balok, menggunting, menulis dan sebagainya. Perkembangan motorik halus dipandang penting untuk dipelajari, karena baik secara langsung maupun tidak langsung akan mempengaruhi perilaku anak setiap hari (Saputra, 2016).

Pengembangan Produk Alat Permainan Edukatif (APE) jenis Balok dapat meningkatkan kualitas pembelajaran pada pendidikan Tanak Kanak-kanak. Hendaknya Guru TK sebagai ujung tombak pelaksana pendidikan Usia Dini (TK), di dalam proses pembelajaran sehari-hari menggunakan APE Jenis Balok yang telah terstandar (telah diadakan uji coba), sehingga kualitas dan hasil belajar akan menjadi lebih baik. Para Pengambil keputusan sebaiknya memberi arahan dan motivasi kepada pelaksana- 
pelaksana pendidikan anak usia dini untuk menggunakan APE sehingga prestasi belajar peserta didiknya akan bisa ditingkatan. Kalangan masyarakat akademik untuk melakukan usaha membuat/merancang model-model alat pembelajaran yang baru yang lebih inovatif untuk memperkaya khasanah Alar Bantu Pembelajaran pada dunia pendidikan anak usia dini (Dimyati, 2011).

Keterampilan motorik adalah kemampuan seseorang untuk melakukan gerakan terkoordinasi menggunakan kombinasi berbagai tindakan otot. Keterampilan motorik halus cenderung dilakukan oleh otot-otot yang lebih kecil seperti yang di tangan dan menghasilkan tindakan seperti menulis dan menggambar (Indriana, 2015).

Dalam perkembangan anak usia dini biasanya keterampilan motorik kasarnya lebih dahulu berkembang dibandingkan dengan motorik halus anak. Hal ini terlihat ketika anak sudah bisa berjalan dengan menggunakan otototot kakinya kemudian anak baru mengontrol tangan dan jarijarinya untuk menggambar atau menggunting. Keterampilan motorik halus anak pada umumnya memerlukan jangka waktu yang cukup lama. Hal ini merupakan suatu proses bagi anak untuk mencapainya. Maka diperlukan identitas kegiatan untuk meningkatkan keterampilan motorik halus anak. Keterampilan motorik halus anak berbeda-beda, ada yang berjalan dengan cepat, ada pula yang sesuai dengan perkembangan tergantung pada kematangan anak (Sujiono, 2010).

Ada beberapa factor yang melatarbelakangi keterlambatan perkembangan motorik halus anak: a) Kurangnya kesempatan untuk melakukan eksplorasi terhadap lingkungan sejak kecil dan pola asuh orang tua yang cenderung over protektif dan kurang dalam memberikan fasilitas dan rangsangan belajar; b) Tidak memberikan kebebasan pada anak untuk mengerjakan aktifitas sendiri sehingga anak terbiasa selalu ingin dibantu oleh orang lain dalam memenuhi kebutuhannya (Madyawati, \& Si, M., 2016).

Prinsip perkembangan motorik menurut Hurlock (1978:151) adalah sebagai berikut: a) perkembangan motorik bergantung pada kematangan otot dan saraf; b) belajar keterampilan motorik tidak terjadi sebelum anak matang; c) perkembangan motorik mengikuti pola yang dapat diramalkan; d) dimungkinkan menentukan norma perkembangan motorik; e) perbedaan individu dalamlaju perkembangan motorik. Hurlock (2001) mengemukakan bahwa saat ideal untuk mempelajari motorik adalah pada masa kanak-kanak dengan alasan: karena tubuh anak lebih lentur dibandingkan dengan tubuh remaja atau orang dewasa sehingga anak lebih mudah mempelajari keterampilan. Anak lebih mudah dan cepat belajar karena keterampilan yang dimiliki masih sedikit sehingga keterampilan yang baru dikuasai tidak mengganggu keterampilan yang sudah ada. Anak bersifat pemberani sehingga ketika belajar anak tidak terhambat oleh rasa takut akan sakit atau diejek teman. Berbeda dengan remaja dan orang dewasa, anak suka melakukan kegiatan yang berulang-ulang, sehingga dengan mengulangulang kegiatan otot menjadi terlatih untuk melakukannya secara efektif.

Tujuan pengembangan motorik halus di usia 4-6 tahun menurut Sumantri (2005) adalah: a) Agar anak mampu mengembangkan kemampuan motorik halus yang berhubungan dengan keterampilan gerak kedua tangan seperti meronce, menganyam, bertepuktangan; b) Agar anak mampu mengkoordinasikan indera mata dan aktivitas tangan; c) Anak mampu menggerakkan anggota tubuh yang berhubungan dengan gerakan jemari: seperti kesiapan menulis, menggambar dan memanipulasi benda-benda; d) Agar anak mampu mengendalikan emosi dalam beraktivitas motorik halus.

Menurut penelitian Febrianingsih di Sleman Yogyakarta tahun 2014 didapatkan Hasil penelitian menunjukkan bahwa tingkat pencapaian perkembangan motorik halus anak kelompok Bdi TK ABA se-Kecamatan Minggir yaitu menggambar tanda plus (+), menggambar tanda silang (x), menggambar bentuk geometri (lingkaran, segiempat, segitiga), menyalin kata, menyalin angka 1-15, menggunting, menempel, dan meronce sebagian besar berada pada kategori BSH (Berkembang Sesuai Harapan). Secara keseluruhan dari 10 indikator dapat dilihat bahwa tingkat pencapaian perkembangan motorik halus anak kelompok Bdi TK ABA se-Kecamatan Minggir dari 223 anak tidak ada yang berada pada kategori Belum Berkembang (BB), 2 anak atau sebesar $0,9 \%$ berada pada kategori Mulai Berkembang (MB), 140 anak atau sebesar $62,78 \%$ berada pada kategori Berkembang Sesuai Harapan (BSH), dan 81 anak atau sebesar $36,32 \%$ berada pada kategori Berkembang Sangat Baik (BSB) (Wadi'in, 2018).

Kemampuan motorik halus anak dapat dilatih di sekolah dan di rumah dengan mensosilisasikan KPSP dan 10 Indikator untuk mengetahui perkembangan motorik halus. Bermain adalah keseluruhan akivitas yang dilakukan oleh seseorang individu yang sifatnya menyenangkan, menggembirakan, dan 
menimbulkan kenikmatan yang berfungsi untuk membantu individu mencapai perkembangan yang utuh, baik fisik, intelektual, sosial, moral dan emosional (Elfiadi, 2016). Fungsi bermain edukatif dalam buku education Games, Andang Ismail mengatakan memberikan Ilmu Pengetahuan kepada anak melalui proses pembelajaran sambil bermain,merangsang pengembangan daya pikir, daya cipta, dan bahasa agar mampu menumbuhkan sikap mental serta akhlak yang baik, menciptakan lingkungan bermain yang menarik, memberi rasa aman dan menyenangkan, meningkatkan kualitas pembelajaran anak (Andang, 2006). Bermain bagi anak usia dini sangat penting karena melalui bermain, anak mengalami proses pembelajaran, bermain sudah menjadi kebutuhan alamiah tiap anak yang harus dipenuhi (Lestari, 2013).

Pada saat ini di Indonesia telah dikembangkan program untuk anak-anak prasekolah yang bertujuan untuk menstimulasi perkembangan anak sedini mungkin, dengan menggunakan APE (alat permainan edukatif). APE adalah alat permainan yang dapat mengoptimalkan perkembangan anak disesuaikan dengan usianya dan tingkat perkembangannya, serta berguna untuk pengembangan aspek fisik (kegiatan-kegiatan yang menunjang atau merangsang pertumbuhan fisik anak), aspek bahasa (dengan melatih berbicara, menggunakan kalimat yang benar), aspek kecerdasan (dengan pengenalan suara, ukuran, bentuk, warna dll.), dan aspek sosial (khususnya dalam hubungannya dengan interaksi antara ibu dan anak, keluarga, dan masyarakat) (Kania, N. 2006).

Alat permainan adalah semua alat yang digunakan oleh anak untuk memenuhi naluri bermainnya dan memiliki pelbagai macam sifat seperti bongkar pasang, mengelompokkan, memadukan, mencari padanan, merangkai, membentuk, mengetok, menyempurnakan suatu desain atau menyusun sesuaibentuk utuhnya. Tingkat pencapaian perkembangan motorik halus anak usia 5-6 Tahun dalam Permendiknas No.58 tahun 2009 yaitu: a) Anak mampu menggambar sesuai gagasannya atau ide; b) Anak mampu meniru berbagai macam bentuk; c) Anak mampu melakukan eksplorasi dengan berbagai media dan kegiatan; d) Anak mampu menggunakan alat tulis dengan benar; e) Anak mampu menggunting sesuai dengan pola; f) Anak mampu menempel gambar dengan tepat; g) Anak mampu mengekspresikan diri melalui gerakan menggambar secara detail.

Metode pembelajaran yang sering digunakan untuk pengembangan motorik halus pada masing-masing TK kurang lebih sama, yaitu metode demonstrasi. Guru mendemonstrasikan kegiatan yang akan dilakukan kemudian guru memberi tugas kepada anak. Penilaiannya menggunakan hasil karya anak, penugasan, unjuk kerja, maupun observasi. Media pembelajaran yang paling sering digunakan adalah lembar kerja anak (LKA). Proses belajar mengajar merupakan interaksi yang dilakukan antara guru dengan peserta didik dalam suatu situasi pendidikan atau pengajaran untuk mewujudkan tujuan yang ditetapkan. Ketika memilih suatu metode yang akan dipergunakan dalam program kegiatan anak di TK diperlukan faktor-faktor yang mendukung pemilihan metode tersebut antara lain karakteristik tujuan kegiatan dan karakteristik anak.Jadi metode pembelajaran adalah pendekatan atau cara yang dipilih dan digunakan oleh guru untuk melaksanakan pembelajaran sehingga tujuan kegiatan dapat dicapai.

Pengaruh stimulasi Alat Permainan Edukatif (APE) terhadap perkembangan motorik halus anak usia 4-5 tahun di RA Baitul Karim Surabaya.Berdasarkan hasil uji statistika dengan menggunakan uji paired samples $t$ test sebelum dan sesudah diberikan stimulasi Alat Permainan Edukatif (APE) didapatkan nilai kemaknaan $\rho$ value $=0,000$ dimana $\rho$-value $<0,05$ yang berarti $\mathrm{H}_{0}$ ditolak yang artinya ada pengaruh stimulasi Alat Permainan Edukatif (APE) terhadap perkembangan motorik halus anak usia 4-5 tahun di RA Baitul Karim Surabaya.Perkembangan Motorik Halus Usia 4-5 Tahun Sesudah Diberikan Stimulasi Alat Permainan Edukatif (APE). Sesudah diberikan stimulasi Alat Permainan Edukatif (APE) sebagian besar 97\% anak mempunyai perkembangan motorik halus yang sesuai dan $1 \%$ perkembangan motorik halus meragukan. Hasil penelitian didapat anak mampu menggambar lingkaran, mampu menyusun 8 kubus, mampu menunjukkan garis yang lebih panjang, mampu menggambar tanda + , mampu menggambar orang dan mampu menggambar sedikitnya 6 bagian tubuh. Penilaian inididapatkan pada saat observasi sesudah diberikan intervensi menggunakan KPSP. Berdasarkan hasilstudi pendahuluan yang dilakukan terdapat 50 anak yang usia 4-6 tahun. Dari jumlah tersebut 30 anak (60\%) diantaranya tidak terpenuhi kebutuhan bermainnya, sedangkan sisanya 20 anak (40\%) dibiarkan untuk mencari permainan sendiri bersama saudara-saudaranya. Sehingga dapat menyebabakan motorik halus anak tidak dapat berkembang dengan maksimal. Adanya kenyataan dari hasil penelitian yang menunjukkan bahwa tingkat peran ibu sebagian besar hasilnya cukup, akan tetapi perkembangan 
anak termasuk dalam kriteria normal dapat disebabkan karena ibu sudah membantu dalam memilihkan alat permainan untuk anaknya. Dalam kesehariannya anak sudah dapat berkumpul, berkomunikasi dan bermain dengan ibu dan teman-teman sebayanya sehingga anak memperoleh stimulasi dengan sendirinya. Peran ibu dalam pemilihan alat permainan sangat penting dalam menunjang perkembangan motorik halus anak. Oleh karena itu sesering mungkin kita memberi himbauan kepada ibu agar mendampingi anak saat bermain, dan memilihkan mainan yang tepat sesuai usianya, sehingga perkembangan motorik halus anak dapat berkembang secara optimal (Yuliawati, 2012).

\section{DAFTAR PUSTAKA}

Andriana, D. (2011). Tumbuh kembang \& terapi bermain pada anak. Jakarta: Repositori Riset Kesehatan Nasional.

Andang, I. (2006). Education Games (Menjadi cerdas dan ceria dengan permainan edukatif). Yogyakarta: Pilar Media.

Bakhtiar, S. (2015). Merancang pembelajaran gerak dasar anak. Padang: UNP Press.

Bloom, B. S. (1976). Human characteristics and school learning. McGraw-Hill.

Dimyati, J. (2011). Pengembangan Alat Permainan Edukatif (Ape) Jenis Balok Untuk Meningkatkan Kualitas Pembelajaran Di Taman Kanak-Kanak. KHAZANAH PENDIDIKAN, 3(2).

Elfiadi, E. (2016). Bermain dan Permainan Bagi Anak Usia Dini. ITQAN: Jurnal Ilmu-Ilmu Kependidikan, 7(1), 51-60.

Febrianingsih, R. (2014). Tingkat Pencapaian Perkembangan Motorik Halus Anak TK aba Kelompok B se Kecamatan Minggir Sleman Yogyakarta. [Skripsi]. Yogyakarta: Universitas Negeri Yogyakarta.

Gunarti, W., \& Muis, A. (2014). Metode Pengembangan Perilaku dan Kemampuan Dasar AUD. Tinjauan Mata Kuliah. Jakarta: Univesitas Terbuka.

Hasanah, U. (2016). Pengembangan kemampuan fisik motorik melalui permainan tradisional bagi anak usia dini. Jurnal Pendidikan Anak, 5(1).

Harlisa, M., Amalia, A., \& Dadang, K. (2010). Hubungan Pengetahuan Ibu Tentang Alat Permainan Edukatif (APE) dengan Pemberian APE pada Anak Usia 4-6 Tahun di TK Srirande 02 Kecamatan Deket Kabupaten Lamongan.. Jurnal

\section{SIMPULAN}

Semakin anak diberi stimulasi APE maka perkembangan motorik halus anak sesuai perkembangan. Pemantauan tubuh kembang di TK dapat menggunakan KPSP untuk mengetahui ada tidaknya gangguan perkembangan. Alat permainan edukasi untuk perkembangan motorik halus dapat di lakukan dengan menulis, meronce,menyusun puzzle, mewarnai, menyusun balok-balok dan menggunting. Dibutuhkan kerjasama orang tua dan guru dalam menstimulasi perkembangan motorik halus anak.

Surya, Vol 1, No 5. STIKES Muhammadiyah Lamongan.

Hurlock, E. B. (2001). Developmental psychology. Tata McGraw-Hill Education.

Indriana, U. (2015). Hubungan Antara Kegiatan Menggambar Dengan Perkembangan Motorik Halus Pada Anak Usia Dini Di Paud Aisyah Desa Karang Pranti Kecamatan Pajarakan Kabubaten Probolinggo. [Skripsi]. Jember: Universitas Jember.

Kemenkes, R. I. (2015). Profil kesehatan Indonesia tahun 2014. Jakarta: Kemenkes RI.

Kania, N. (2006). Stimulasi tumbuh kembang anak untuk mencapai tumbuh kembang yang optimal. In Disampaikan pada seminar "Stimulasi Tumbuh Kembang Anak". Bandung (Vol. 11).

Karli, H., \& Hutabarat, O. R. (2007). Implementasi KTSP dalam model-model pembelajaran. Jakarta: Erlangga.

Lestari, S. (2013). Implementasi Education Games Dalam Pembelajaran di TK Islam Pelangi Anak Umbulharjo Yogyakarta. Repository Universitas Islam Negeri Sunan Kalijaga Yogyakarta.

Madyawati,L., \&Si, M. (2016).Strategi pengembangan bahasa pada anak. Kencana.

Mutiah, D. (2015). Psikologi bermain anak usia dini. Kencana.

Nursalam, dkk. (2005). Asuhan Keperawatan Bayi dan Anak. Jakarta: Salemba Medika.

Permendiknas, R. I. (2010). No 58 Tahun 2009. Standar Pendidikan Anak Usia Dini. Jakarta. 
Saputra, W. N. E., \& Setianingrum, I. (2016). Perkembangan motorik halus anak usia 3-4 tahun di kelompokbermain cendekia kids school madiun dan implikasinya pada layanan konseling. Jurnal CARE (Children Advisory Research and Education), 3(2), 1-11.

Sain, S. N. H., Ismanto, A. Y., \& Babakal, A. (2013). Pengaruh Alat Permainan Edukatif terhadap Aspek Perkembangan pada Anak Pra Sekolah di Wilayah Puskesmas Ondong Kabupaten Kepulauan Siau Tagulandang Biaro. e-NERS, 1(1).

Sulistyawati, A. (2014). Deteksi tumbuh kembang anak. Jakarta: Salemba Medika.

Sujiono, B., Sumantri, M. S., \& Chandrawati, T. (2010). Hakikat Perkembangan Motorik Anak. Modul PGTK, Universitas Terbuka.
Sumantri, M. S. (2005). Model Pengembangan Keterampilan Motorik Anak Usia Dini. Jakarta: Depdiknas.

Yuliawati, A., \& Subiyatun, S. (2012). Hubungan Peran Ibu dalam Pemilihan Alat Permainan dengan Perkembangan Motorik Halus Anak Usia 4-6 Tahun di Yayasan ARRahmah Kebumen Lumajang. [Skripsi]. Yogyakarta: Stikes Aisyiyah Yogyakarta.

Wadi' in, N. S. M., Hasmalena, H., \& Rukiyah, R. (2018). Pengembangan buku paper quilling berbasis tema untuk motorik halus anak usia 5-6 tahun di tkit robbani indralaya. [Skripsi]. Palembang: Universitas Sriwijaya. 